\title{
Language Behavior of Malay Society in Barus
}

\author{
Roma Ayuni A. Loebis \\ Faculty of Cultural Studies, University of Sumatera Utara \\ romaloebis@gmail.com
}

\begin{abstract}
This research analyses and discusses "refusal strategies"as the reflection of language behavior and socio-culture of language society in Barus which has multi-languages such as Minangkabau, Batak and Aceh, also coastal ethnic languages as Malay root language."Refusal strategies" is not only a part of Speech Act, but also another form of language behavior which occurs in daily activities in responding request, invitation, offer, and suggestion. This research uses qualitative descriptive method. The data are collected by doing observation, questioning informants, and recording dialogues among respondents. Pragmatics approaches which covers ethno-pragmatics, and sociopragmatics will be used. Data are grouped based on Refusal strategies taxonomy by Beebe et.al.:1990 (Triana: 2007 and Hiroko: 2014). The research found that the using of "Refusal Strategies" is not only consider as the language behavior which influenced by norms and culture value. The choice on "Statement of regret" and "Giving explanation" to the interlocutor are preferred than other classifications which also various in usages. The phenomenon is due to the culture effect which is believed by language society in Barus.
\end{abstract}

Key words: refusal strategies, language behavior, language society in Barus

\section{INTRODUCTION}

As a sub-study of Linguistics that examines how context supports meaning, Pragmatic research is often done. It is not just broad Pragmatic coverage, but because Pragmatics refers to the language skills in society that are used daily in interacting with others.Language understanding shows on the fact that to understand an expression/speech language it is also necessary to outsource the meaning of words and grammatical relationships that relate to the context of using it and [1] the term "linguistic proper" also used to mention this linguistic approach [2].

One of the studies in Pragmatics is Speech Act. Speech Act covers refusal strategy which is a response to request, invitation, offer, and suggestion. Under normal circumstances, acceptance and approval is always the expected countermeasures when refusal is not expected. However, delays also sometimes indicate that speakers have a strong reason for a refusal.
The pragmatic paradigm is the exposure to be associated with the sociocultural state of the speaker. In other words, the pragmatic study of Malay speech has not shown the study that puts language analysis and social analysis in a proportional context. Some categorized this study to speechact analysis as a communication medium [3]. In fact, the study of the actual speech can explain the linguistic aspects and simultaneously explain the social processes that apply in the community of speakers who are pleased. This is why the pragmatic study of Malay speech does not touch social life.

Barus is a regency in about $290 \mathrm{~km}$ from Medan. It is an old town which lay at the coastal Central Tapanuli, known as the first place Islam arrived and spread inIndonesia. The residents of Barus beach consists of many Malays who come from Minangkabau and from the more southerly coastal ports; Bataknese who have wandered to the beach and more or less have made a marriage with beach residentsand other groups including Acehnese [4]. Speech in Barus community, especially the speakers of Malay will become more important if studied in the context of the latest social life, namely life in the global era that is identified with the era of cultural transformation. Cultural transparency can have an impact on the language, norms and values that ethnic practices speak of, as stated [4] that "the major elements of culture are language, norms, beliefs, and values." Language as a system symbols that cannot be separated from norms and culture values because it is created and used by people who have the norms and culture values. Pragmatics examines the factors that drive the choice of language in social interaction and the influence of that choice to the partners [2]. In this theory we can say something as we please, but in practice we have to follow a number of social rules (largely unconscious) that we must follow.

Therefore, a study is needed that can analyze linguistic aspects based on the latest development of Malay society and culture, called Malay language behavior study. In this research, Malay speech study framework is used to explore linguistic aspects and sociocultural behavior of refusal. The choice of refusal is also because the study of refusal is still very little compared to other [5] even from a sociolinguistic standpoint [6], much less in the context of Malay culture. Research focusing on refusals, by Beebe and Takahashi [1] [7] [8].

The theory of cultural scripts 'cultural discourse' deals with the communication of humans or groups of 
people from a cultural perspective. In different societies, people or groups of people not only have different languages, but they use those languages in different ways. In some societies, for example, communication or conversation often occurs because of disagreements, tension or tone of voice increases, emotions are so loose. Meanwhile, in other societies, people or groups avoiding conflict and tension, they speak in coolness, and even in a soft tone of voice. [9]Thiscultural script can be applied to examine cross-cultural emotions, to see how emotional differences in feelings in communication [10]. The selection of ethnic Malay in Barus is more due to the suitability of the nature of the study framework to the social reality that appears in the present social phenomenon or in the historical record. Compatibility can be observed through the philosophy of life the nature of social, customs, and ethnic Malay role in the life of nation and state.

\section{METHOD}

This study uses a qualitative descriptive approach. A descriptive approach can be interpreted as a problemsolving procedure that is investigated by describing the state of the research subject (person, institution, community and others), which is now based on facts that appear and as it is [5].The study of speech acts of the Malay community is intended as a study that sees speech behavior as a form of social behavior which is realized through verbal language. The paradigm used in the study is a Socio-pragmatic paradigm that developed through the ethnographic approach. The data are collected by the ethnographic rules of speechthat proposedby the SevilleTroike, which includes observation techniques and interviews. The data is taken in informal situations that focus on the conversation.

This research was donein January 2018 with duration of about 3-4 hours in a day. Referring to the consideration and process of determining the corpus [11], the corpus of data studied are 121 speech- events involving 102 participants from random areas in Barus. The tools used are handy-cam and voice-recorder. Data analysis is done qualitatively. The analysis is using Beebe et.altheory with taxonomy. The analysis of speech behavior refers to [12] rhetorical analysis that is more fundamental to the principle of speech rather than to the sentence. Analysis of social culture refers to theories of cultural change [13].

\section{DISCUSSION}

In a speech acts often occur where the second speech is a sequence of the first one which is called an adjacency pair. This situation occurs when the speech is produced by two or more participants. One of the speech constructed as a response to the previous speech is a refusal. Refusal is a form of response to a request, offer, gift, suggestion, award or praise, invitation or order from one or more participants involved in a speech.
The results that the refusalamong between friends among Malay speakers in Barus is variously disaggregated. Researcher indicate that the strategy of refusal among Malay speakers can be clarified to 7 (seven) strategies.

Table 1: Frequent Usage of Refusal Strategies based on age

\begin{tabular}{lcccccccc}
\hline \multirow{2}{*}{ Refusal Strategies } & \multicolumn{6}{c}{ Usage } \\
\cline { 2 - 9 } & $\begin{array}{c}\text { Amount } \\
\mathbf{( \% )}\end{array}$ & $\mathbf{F}$ & $\mathbf{M}$ & $\begin{array}{c}\text { Total } \\
\mathbf{( \% )}\end{array}$ & $\mathbf{F}$ & $\mathbf{M}$ & $\begin{array}{c}\text { Total } \\
\mathbf{( \% )}\end{array}$ \\
\cline { 3 - 9 } & $23(14.5)$ & 2 & 5 & $7(3.04)$ & 9 & 7 & $16(6.95)$ \\
\hline Direct refusals & $22(13.9)$ & 6 & 9 & $15(6.81)$ & 4 & 3 & $7(3.18)$ \\
\hline Shows regrets & $23(14.5)$ & 6 & 8 & $14(6.08)$ & 3 & 6 & $9(3.91)$ \\
\hline Gives explanation & $23(14.5)$ & 9 & 7 & $16(6.95)$ & 3 & 4 & $7(3.04)$ \\
\hline Give other choices/alternatives & $25(15.8)$ & 5 & 4 & $9(3.6)$ & 9 & 7 & $16(6.4)$ \\
\hline State principles & $20(12.6)$ & 2 & 1 & $3(1.5)$ & 7 & 5 & $12(8.5)$ \\
\hline Provides unclear reply & $22(13.9)$ & 8 & 7 & $15(6.81)$ & 5 & 2 & $7(3.18)$ \\
\hline Be grateful & $158(100)$ & 38 & 41 & $79(53.17)$ & 40 & 34 & $74(46.83)$ \\
\hline Total & & & & & &
\end{tabular}

Refusal Strategy among the Malay language in Barus

It can be seen on the table that refusal strategies which are used are 1) Direct refusal, 2) Express regret, 3) Apologize and give reasons / explanation 4) Give choice of other things, 5) State the principle of refusal, 6) give unclear replies, and 7) Be grateful.

\section{Direct Refusal}

Direct refusal occursagainst long-known or familiar opponents. Word is used explicitly and directly. The word used is the word rejection like tidak, ndak. This strategy is more dominantly used by young people who mostly use direct speech.

\section{Stating Regret}

This strategy is widely used among adult at higher age. Generally, it uses the words ambomenyesal..., sedihrasonyotidakdapatmembantu.

\subsubsection{Apologize and give a reason/ explanation}

This strategy is the most widely used Malay speakers in Barus. Apologies are expressed in order to maintain politeness and interlocutor can understand. Giving a reason is meant as a step to form a polite refusal. Refusing for explicit reasons can be identified through the use of a conjunctive word, such as kerano, and sobab. This strategy is used to refuse friends with different types and levels of relationships. The findings indicate that this strategy is often used by the Malay-speaking community in Barus in refusing.

\section{Giving choice to something else}

The strategy of giving choice to other things aims to give way out of the conditions experienced by the interlocutor. Actually speakers cannot undertake the request, command from the interlocutor so that speakers propose other options. This strategy is used to neutralize the atmosphere of speech and avoid conflict. Therefore, this strategy is often used by Malay speakers in Barus to interact, regardless of the type and level of participant relationships. 


\section{Expressing the principle of life}

Statement of principle of life like ambo ndak biaso baniaga seperti ini ... to suggestion generally happened among adult age group which indicates that a person has a life principle in living his life so that he can refuse the offer or invitation of the interlocutor.

\section{Providing an unclear reply}

This strategy is generally used if the Malay speakers in Barus do not recognize the interlocutor. Generally the refusal is in the form of silent action or dodge.

\section{Be Grateful}

Grateful strategy is commonly used by Malay speakers in Barus as a greeting to refuse a request or an offer Words like terimakasih ... are used to maintain the politeness and respect and to keep the feelings of the interlocutor.

The results indicate that the old Barus society practices the refusal strategy by politeness, as well as the young ones. Young people seem to be starting to imitate older people in speaking style. The speakers of Malay in Barus who adhere to norms and custom values seem to try to maintain the Malay tradition. In other words, the elderly still want and continue to perpetuate the cultural values in refusing. The youth are also learning practice the values though not so obvious.

The change in values is also found in the behavior of refusal strategies by gender. It is found that "Giving another choice" and "Stating principles" are dominated by women. This may be due to the reinforcement of cultural development among female speakers. Thisfinding can be considered interesting, because normally in every culture, women arepsychological constructed as a weak and emotional speaker.

\section{CONCLUSIONS}

Various strategiesin refusing among Malay speakers in Barusare closely related to the speaker's social aspect and his language behavior. The variety shows the tendency of Malayspeakers can be clarified based on the social aspect of the speakers, the age group and gender. The dual variables provide a meaningful variation for the phenomenon of refusing among Malay speakers in Barus. Refusing is not a single activity, but an activity supported by socio-cultural values and norms.

The rules in speech acting are not always able to be obeyed by every member of the community although it is realized that by obeying the rules, success in interaction can be achieved. The reasons of condition, emotion, and logical aspects make the rules may not be obeyed or not practiced. Therefore, deviation of the rules is not a barrier thing; basically the deviation of rules is just a manifestation of changes in a dynamic society. Especially in Barus live various ethics, which in daily interaction, cultural factors-especially in speaking-more likely impact each other.

\section{REFERENCES}

[1] Triana, Hetti Waluati. "Strategi Menolak: Cermin Dinamika Sosial”. Jurnal WACANA, Juli 2008 Vol.11, No.2. 2008

[2] Fairclough, Norman. "Language and Power" Harlow England:Longman. 2001

[3] Akmajian, A (et.al.). Linguistic: "An Introduction to Language and Communication".Cambridge Mass: MIT Press. 1990

[4] Drakard, Jane. "Sejarah Raja-Raja Barus". Jakarta: Gramedia. 2003

[5] Nawawi, Hadari. "Penelitian Terapan". Yogyakarta: Gajah Mada University Press. 2005

[6] Beebe, Leslie. M, Takahasi, T., \&UlissWeltz, R. "Pragmatic Transfer in ESL. Refusal in Developing Communication Competence in a Second Language". New York: Newburry Hills.1990

[7] Santoso, Wahyudi Joko dkk. "Bentuk, Strategi Penggunaan dan Kesantunan Tindak Tutur Menolak dalam Interaksi antar Mahasiswa Prodi Sastra Prancis FBS Unnes."Fakultas Bahasa dan Seni Unnes. 2010

[8] Hiroko. TsuikiMoaveni. "A Study of Refusal Strategies by American and International Student at an American University". Manhattan: Minnesota State University. 2014

[9] Goddard, C. "Directive Speech Act in Malay: Ethnopragmatic Perspective" in Speech Issue on Intercultural Communication. 2003.

[10] Wierzbicka, Anna. "Language, Culture and Meaning: Cross-Cultural Linguistics". Amsterdam: John Benjamins Publishing. 1999.

[11] Samarin, William J. "Field Linguitics: A Guide to Linguistics Field Work". California: Holt, Rinehart and Winston. 1967

[12] Leech, Geoffrey. "Principles of Pragmatics". London: Longman. 1983

[13] Saville-Troike, Muriel. "The Ethnography of Communication: An Introduction. Oxford: Blackwell Ltd. 1989

[14] Anderson, Margaret L.\& Howard Francis Taylor. "Sociology: Understanding a Diverse Society": Thomson/Wadsworth

[15] Giddens, Antony. "Sociology". Cambridge BlackwellPublishing Ltd. 2005.

[16] Levinson, S.C. "Pragmatics". Cambridge: Cambridge University Press. 1991 